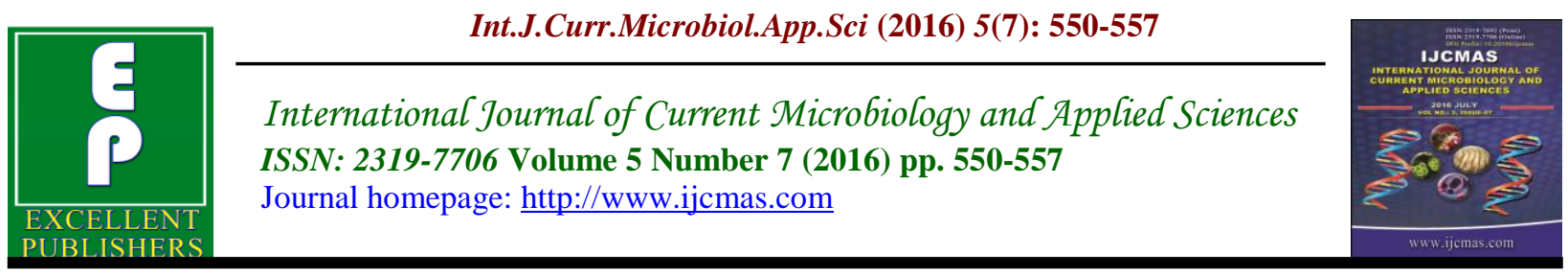

Original Research Article

http://dx.doi.org/10.20546/ijcmas.2016.507.060

\title{
Prevalence and Status of Major Fungal Foliar Diseases of Cucumber in Western Himalayan State of Jammu \& Kashmir, India
}

\author{
Shanaz Yousuf and G.H. Dar* \\ Division of Plant Pathology, Sher-e-Kashmir University of Agricultural Science and \\ Technology of Kashmir, Shalimar campus, Srinagar - 190 025, Jammu \& Kashmir (India) \\ *Corresponding author
}

\section{A B S T R A C T}

\section{Keywords}

Alternaria leaf spot, anthracnose, cucumber, disease incidence, downy mildew, powdery mildew.

\section{Article Info}

Accepted:

20 June 2016

Available Online:

10 July 2016
The prevalence and status of major fungal foliar diseases in cucumber (Cucumis sativus L.) in Western Himalayan state of Jammu \& Kashmir was assessed in 2011 and 2012. A field survey was conducted in four commercial vegetable growing districts viz., Baramulla, Srinagar, Bandipora and Budgam in active growth period of the crop which revealed downy mildew, anthracnose, Alternaria leaf spot and powdery mildew to be the predominant diseases. The mean disease incidence of downy mildew, anthracnose, Alternaria leaf spot and powdery mildew was 34.0, 34.7, 35.5 and 33.0 and 41.3, 47.2, 45.6 and 39.7\%, respectively, during 2011 and 2012. The mean disease intensity of respective diseases was 14.1, 16.1, 13.3 and 14.1 and 17.6, 20.8, 16.1 and 16.6\% during 2011 and 2012. The highest incidence of these diseases, except powdery mildew, was observed in Srinagar while powdery mildew incidence was highest in Baramulla. These diseases need special attention in devising protection strategies of the crop.

\section{Introduction}

Cucumber (Cucumis sativus L.), belonging to the family Cucurbitaceae, is one of the oldest cultivated vegetable which originated from South Asia (Wehner and Robinson, 1991; Doijode 2001; Renner et al., 2007). Worldwide cucumber ranks $4^{\text {th }}$ most widely cultivated vegetable crop after tomato, cabbage and onion (Shetty and Wehner, 2002). Cucumber is a creeping vine that bears cylindrical fruits which are mostly used for culinary purpose and occasionally for non-food use. The fruits are eaten afresh as salad, pickle or cooked. Global cucumber production is 71.36 million tonnes procured from 2.11 million ha area with yield value of
33.5 t/ha (FAOSTAT, 2013). About $80 \%$ world cucumber production occurs in Asia alone with China as a leading producer (Wehner and Maynard, 2003). Cucurbits including cucumber share about $5.6 \%$ of total vegetables produced in India and according to FAO estimate cucurbit crops in India are cultivated on about 4.29 million ha with the productivity of $10.52 \mathrm{t} / \mathrm{ha}$ and is widely grown in all states, including Jammu and Kashmir.

Since cucumber is a tender crop, therefore, it is frost susceptible and suffers much from various biotic attacks. Like many cucurbit 
crops, cucumber is prone to a number of fungal, bacterial and viral diseases which cause inflict serious economic losses to the crop. Yield losses due to various fungal diseases in cucumber are reported to be 10$20 \%$ when appropriate remedial measures are not taken (Del Pino et al., 2002; Balai and Ahir, 2013). Colucci et al. (2006) reported that in USA cucumber yield losses from downy mildew alone though less until 2004 reached $40 \%$ when a more virulent form of causal pathogen Psuedoperonospora cubensis emerged. In India, the prevalent fungal diseases on cucumber include downy mildew, powdery mildew, anthracnose, leaf spots, damping off, wilt, scab, crown and root rot (Zitter et al., 1998; Saha, 2002). In India no major work has been done on the status of major diseases in cucumber. Gupta at al. (2014) reported downy mildew incidence and intensity of 70 and 56\%, respectively, in cucumber. Hence the present study was aimed to assess the status of fungal diseases prevailing in Himalayan state of Jammu \& Kashmir on cucumber so that future strategies for crop protection are devised with focus on major diseases.

\section{Materials and Methods}

A field survey for the assessment of major foliar diseases in cucumber was conducted in four districts of Jammu \& Kashmir state viz., Srinagar, Budgam, Bandipora and Baramulla in the months of July and August (peak periods of diseases) in the years 2011 and 2012. From each district five locations were randomly selected. The sites selected in district Baramulla were: i) Sopore, ii) Baramulla, iii) Pattan, iv) Janwara and v) Seelu; in district Srinagar i) Kawoosa, ii) Dal, iii) Shalimar, iv) Shadipora and v) Harwan, in district Bandipora i) Patushai, ii) Nadihal, iii) Kemah, iv) Aloosa and v) Ongam and in district Budgam i) Batpora, ii) Sheikhpora, iii) Gangbug, iv) Kremshora and v) Narkara. From each location three vegetable fields were chosen and in each field ten random plants were selected and from each plant twenty five leaves were assessed to record the incidence and intensity of various diseases. Separate leaves were examined for each disease. The intensity was recorded on the same leaves used for recording the incidence. The meteorological data with respect to temperature, rainfall and relative humidity for the growth period was collected from the Division of Agronomy, SKUAST-Kashmir, Shalimar.

The disease incidence for each disease of cucumber was recorded by counting the total number of leaves and the number of infected leaves. The per cent disease incidence for each disease was calculated as per formula adopted by Kalloo (1997):

$\begin{array}{ll}\text { Per cent disease } & \begin{array}{l}\text { Number } \\ \text { infected leaves }\end{array} \\ \text { incidence }= & \begin{array}{l}\text { Total number of } \\ \text { leaves examined }\end{array}\end{array}$

The per cent disease intensity for each disease was recorded by visual observation using 0-5 scale adopted by Singh et al. (1996), wherein $0=$ no disease, $1,2,3,4$ and 5 represented 1-10, 11-25, 26-50, 51-75 and $\geq 75$ leaf area affected by disease, respectively. The per cent disease intensity (PDI) was calculated as per the formula:

$\begin{array}{ll}\text { Per cent disease } & \sum(\mathrm{x}) \\ \text { intensity }(\mathrm{PDI})= & \mathrm{N} \times \\ \mathrm{S}\end{array}$

Where, $\sum=$ Summation; $\mathrm{n}=$ Number of leaves in each category; $\mathrm{v}=$ Numerical value of each category; $\mathrm{N}=$ Number of leaves examined, and $\mathrm{S}=$ Maximum numerical value. 


\section{Result and Discussion}

During the two year survey various fungal disease were observed on cucumber which included downy mildew, powdery mildew, anthracnose, Alternaria leaf spot, Septoria leaf spot, Ulocldium leaf spot and scab. However, of these only downy mildew (Pseudoperonospora cubensis), powdery mildew (Sphaerotheca fuliginea), anthracnose (Colletotrichum arbiculare) and Alternaria leaf spot (Alternaria alternata) were predominant during both the years at all the sites.

The overall mean disease incidence and intensity of all the predominant diseases was higher in the year 2012 than in 2011 (Fig. 14). More severity of diseases in 2012 than in 2011 may be ascribed to more conducive conditions for pathogenic growth viz., favourable temperature, high relative humidity and more rainfall during the cropping period.

A mean maximum temperature of $29.1^{\circ} \mathrm{C}$, mean minimum temperature of $14.0^{\circ} \mathrm{C}$, relative humidity of $30.9 \%$ and rainfall of $58.7 \mathrm{~mm}$ was recorded during 2011 and a mean maximum temperature of $27.3^{\circ} \mathrm{C}$, minimum temperature of $13.7^{\circ} \mathrm{C}$, relative humidity of $47.3 \%$ and a rainfall of $65.3 \mathrm{~mm}$ in 2012. Conducive temperature and more relative humidity and precipitations appeared to have favoured disease development. Thomas (1977), Rotem et al. (1978) and Reuveni and Reuveni (2000) found a mean temperature of $15^{\circ} \mathrm{C}$ (range: $5-30^{\circ} \mathrm{C}$ ) and presence of leaf moisture ideal for inducing infection and disease spread. Downy mildew incidence ranged from 16.0 to $69.3 \%$ (avg. $34.0 \%$ ) in 2011 and 22.0 to $67.3 \%(41.3 \%)$ in 2012 whereas the downy mildew intensity varied from 8.2 to $20.3 \%$ (avg.14.1\%) in 2011 and 9.9 to $36.2 \%$ (17.6\%) in 2012 (Fig. 1). The occurrence of downy mildew has been reported from all the continents of north and south hemispheres wherever cucumber is grown (Bains and Sharma, 1986; Thakur and Mathur, 2002; Lebeda et al., 2009). The disease affects the foliar part of plants (Thomas, 1996).

The anthracnose incidence in the surveyed sites ranged from 14.6 to $62.6 \%$ (avg. $34.7 \%$ ) during 2011 and 18.6 to $76.6 \%$ (47.2\%) in 2012 (Fig. 2). However, the disease intensity was $6.0-29.7 \%$ (avg. $16.1 \%$ ) during 2011 and $8.1-35.4 \%$ (avg. $20.8 \%$ ) in 2012. Similarly, Alternaria leaf spot incidence varied from 13.3 to $64.0 \%$ (avg. 35.5\%) in 2011 and 23.3 to $68.6 \%$ (avg. 45.6\%) in 2012 while the disease intensity varied from 5.7 to $30.9 \%$ (avg. $13.3 \%$ ) during 2011 and 9.0 to $29.8 \%$ (avg.16.1\%) in 2012 (Fig. 3). Similar findings have been reported by Goldberg (2004) with respect to anthracnose and Garibaldi et al. (2007) and Hubballi et al. (2010) with respect to Alternaria leaf spot.

The mean anthracnose incidence and intensity during both the years at selected sites in Kashmir ranged from 19.6 to 63.3 and 8.9 to $29.1 \%$, respectively (Table 1 ). Amongst the various districts surveyed, the highest mean disease incidence of $57.5 \%$ was observed in Srinagar and highest intensity of $26.9 \%$ in Baramulla. Least mean disease incidence and intensity of 24.4 and $11.2 \%$ was recorded in district Budgam. In case of downy mildew the mean disease incidence and intensity during both the years in selected sites ranged from 20.6 to 63.6 and 9.5 to $29.0 \%$, respectively (Table 1). 
Table.1 Disease incidence and intensity predominant fungal diseases on cucumber leaves in Kashmir [mean of 2 years data (2011 and 2012)]

\begin{tabular}{|c|c|c|c|c|c|c|c|c|c|}
\hline \multirow[t]{2}{*}{ District } & \multirow[t]{2}{*}{ Location } & \multicolumn{2}{|c|}{ Anthracnose } & \multicolumn{2}{|c|}{ Downy mildew } & \multicolumn{2}{|c|}{ Powdery mildew } & \multicolumn{2}{|c|}{ Alternaria leaf spot } \\
\hline & & Inc. & Int. & Inc. & Int. & Inc. & Int. & Inc. & Int. \\
\hline \multirow[t]{5}{*}{ Baramulla } & Sopore & 41.6 & 24.1 & 29.5 & 12.1 & 41.6 & 18.6 & 40.6 & 16.6 \\
\hline & Baramulla & 51.6 & 27.3 & 57.6 & 29.0 & 51.6 & 20.0 & 66.0 & 29.3 \\
\hline & Pattan & 53.6 & 28.8 & 47.6 & 25.7 & 53.6 & 21.3 & 65.9 & 29.5 \\
\hline & Janwara & 60.3 & 23.9 & 63.3 & 31.1 & 60.3 & 23.6 & 59.9 & 24.1 \\
\hline & Seelu & 52.0 & 26.0 & 47.6 & 25.0 & 52.0 & 20.4 & 47.6 & 18.6 \\
\hline \multicolumn{2}{|c|}{ Mean } & 51.8 & 26.0 & 49.1 & 24.5 & 51.8 & 20.8 & 56.0 & 23.6 \\
\hline \multirow[t]{5}{*}{ Srinagar } & Kawoosa & 54.5 & 25.2 & 41.0 & 17.8 & 41.3 & 17.4 & 58.9 & 25.1 \\
\hline & Dal & 56.6 & 24.4 & 63.6 & 32.6 & 52.9 & 22.6 & 53.3 & 22.7 \\
\hline & Shalimar & 63.3 & 29.1 & 59.0 & 26.2 & 46.9 & 20.6 & 60.3 & 26.5 \\
\hline & Shadipora & 52.6 & 22.3 & 38.6 & 16.0 & 41.3 & 18.5 & 52.6 & 21.5 \\
\hline & Harwan & 60.0 & 26.9 & 55.3 & 25.7 & 46.5 & 19.5 & 56.8 & 26.1 \\
\hline \multicolumn{2}{|c|}{\begin{tabular}{|c|} 
Mean \\
\end{tabular}} & $\mathbf{5 7 . 5}$ & 25.5 & 51.5 & 23.6 & 45.7 & 19.7 & 56.8 & 24.4 \\
\hline \multirow[t]{6}{*}{ Bandipora } & Patushai & 29.3 & 12.9 & 29.6 & 9.9 & 26.5 & 12.6 & 30.9 & 12.5 \\
\hline & Nadihal & 24.6 & 11.6 & 30.3 & 11.5 & 24.0 & 10.4 & 26.0 & 10.5 \\
\hline & Kemah & 21.3 & 8.9 & 20.6 & 9.5 & 15.7 & 6.9 & 18.3 & 7.3 \\
\hline & Aloosa & 24.6 & 10.9 & 25.0 & 10.1 & 24.7 & 11.7 & 22.3 & 10.7 \\
\hline & Ongam & 27.3 & 12.7 & 24.3 & 11.0 & 30.2 & 14.2 & 24.9 & 11.2 \\
\hline & Iean & 25.4 & 11.4 & 25.9 & 10.4 & 24.2 & 11.1 & 24.5 & 10.4 \\
\hline \multirow{5}{*}{\begin{tabular}{|l|} 
Budgam \\
\\
\\
\\
\end{tabular}} & Batpora & 35.6 & 16.9 & 24.0 & 12.7 & 29.0 & 12.3 & 32.6 & 13.5 \\
\hline & Sheikhpora & 23.6 & 10.6 & 20.6 & 10.1 & 28.0 & 11.8 & 26.6 & 12.1 \\
\hline & Gangbug & 21.4 & 9.0 & 24.6 & 9.7 & 22.5 & 9.5 & 29.9 & 12.7 \\
\hline & Kremshore & 22.3 & 10.2 & 20.6 & 10.7 & 19.7 & 8.9 & 25.3 & 10.8 \\
\hline & Narkara & 19.6 & 8.9 & 27.6 & 15.7 & 19.0 & 8.5 & 21.9 & 10.4 \\
\hline \multicolumn{2}{|c|}{ Mean } & 24.4 & 11.2 & 23.5 & 11.7 & 23.6 & 10.2 & 27.3 & 11.9 \\
\hline \multicolumn{2}{|c|}{ Overall Mean } & 41.0 & 37.5 & 37.5 & 15.8 & 36.3 & 15.4 & 40.4 & 14.8 \\
\hline
\end{tabular}

Inc. $=$ incidence; Int. $=$ intensity

Fig.1 Mean disease incidence and intensity of downy mildew (Pseudoperonospora cubensis) on cucumber leaves at various locations of Kashmir during 2011 and 2012

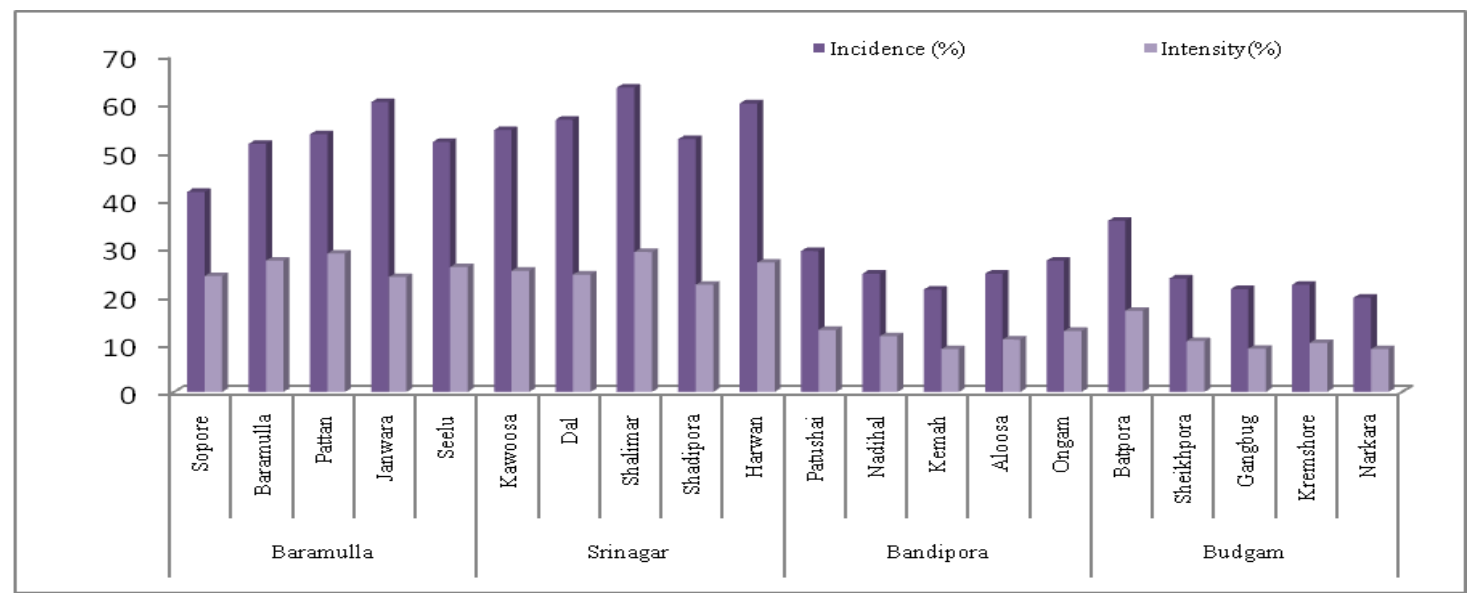


Fig.2 Mean disease incidence and intensity of anthracnose (Colletotrichum arbiculare) on cucumber leaves at various locations of Kashmir during 2011 and 2012

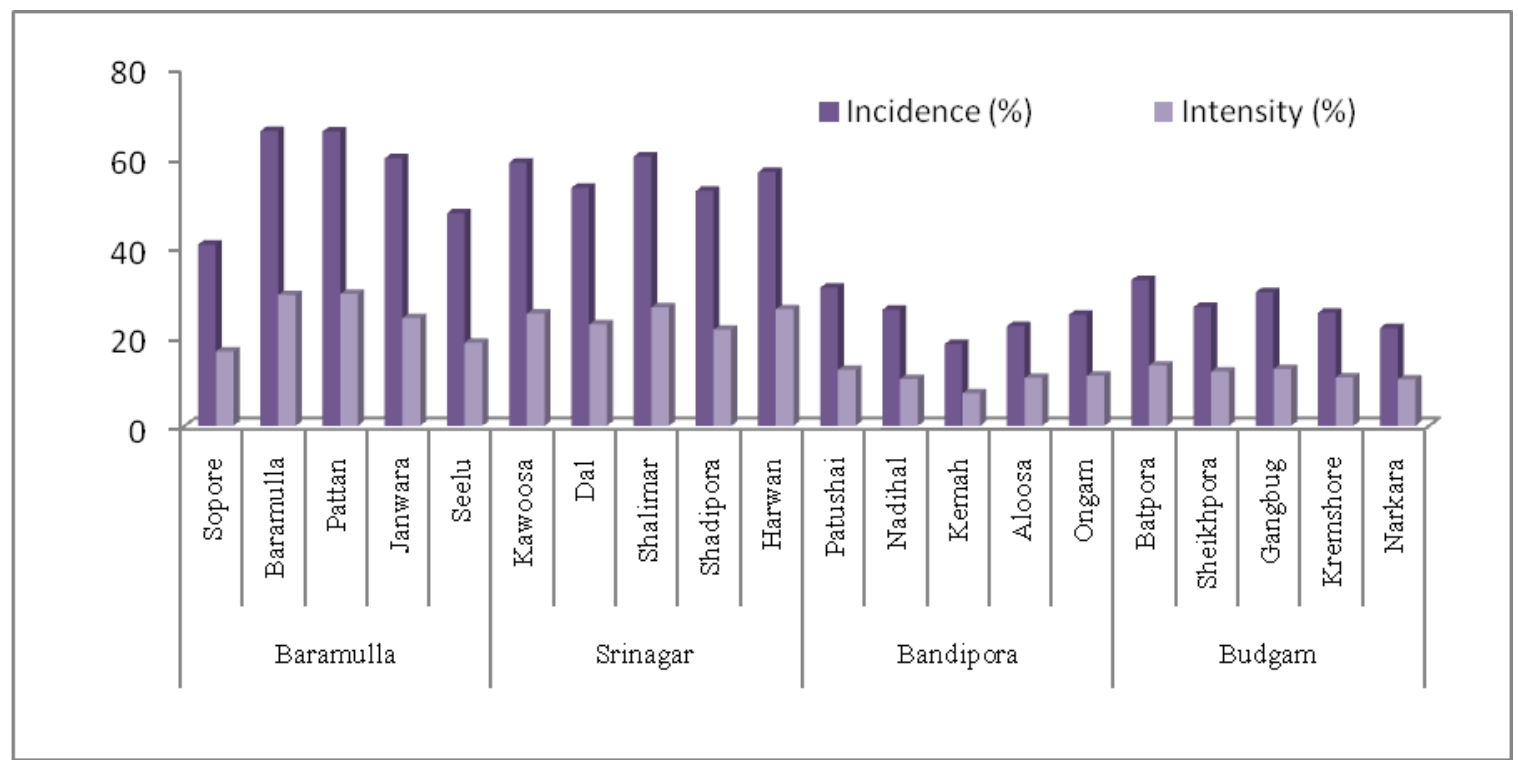

Fig.3 Mean disease incidence and intensity of Alternaria leaf spot (Alternaria alternata) on cucumber leaves at various locations of Kashmir in 2011 and 2012

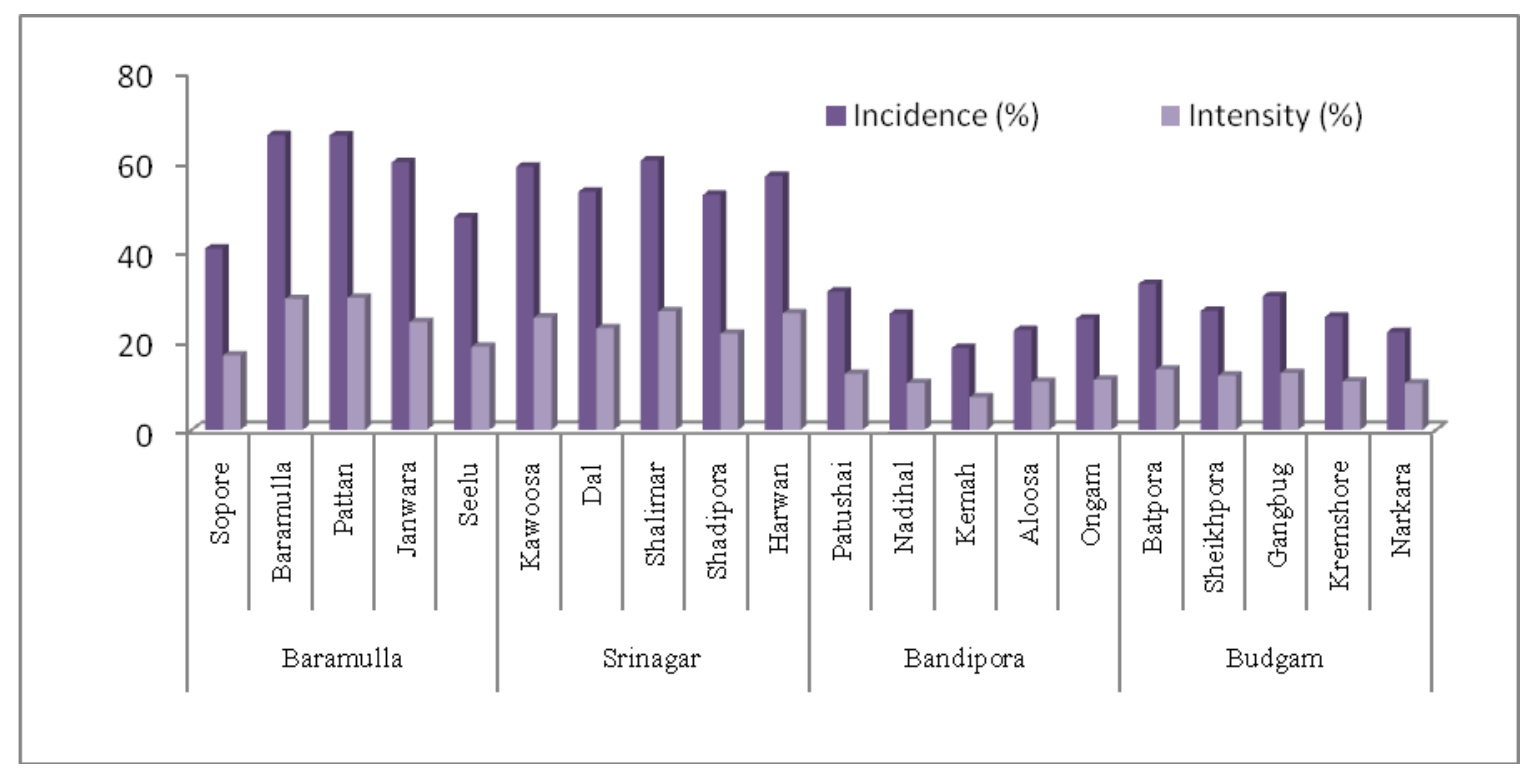


Fig.4 Mean disease incidence and intensity of Alternaria leaf spot (Alternaria alternata) on cucumber leaves at various locations of Kashmir in 2011 and 2012

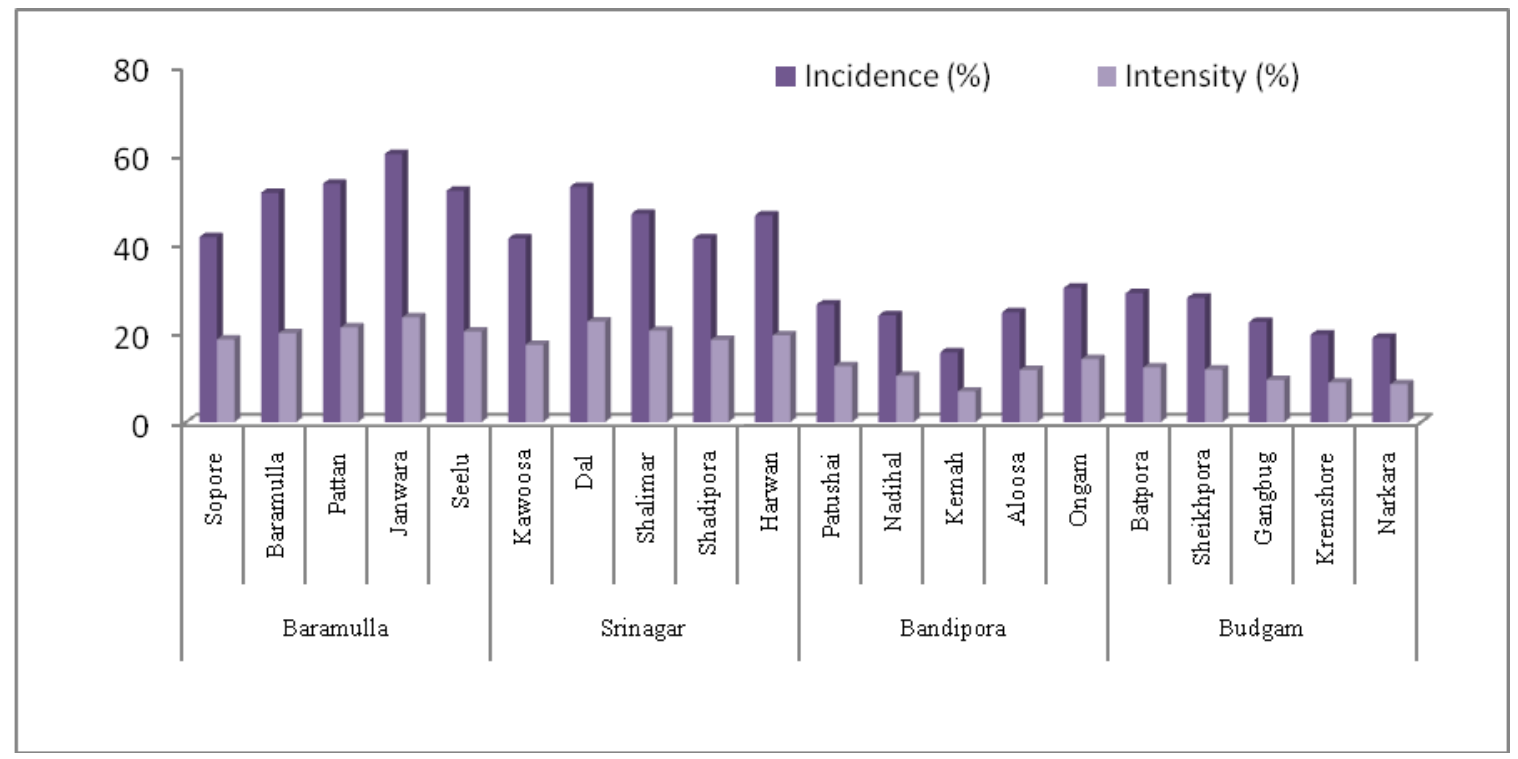

District Srinagar recorded highest mean disease incidence of $51.5 \%$, followed by district Baramulla (49.1\%) and least mean disease incidence and intensity of 23.5 and $11.7 \%$ was noticed in district Budgam. In case of Alternaria leaf spot the mean disease incidence and intensity during both the years ranged from 18.3 to 66.0 and 7.3 to $29.5 \%$, respectively. The highest mean disease incidence of $56.8 \%$ was noticed in Srinagar closely followed by Baramulla (56.0\%) and least mean disease incidence and intensity of 23.5 and $11.7 \%$ was observed in district Budgam. The mean powdery mildew incidence and intensity during both the years ranged from 15.7 to 60.3 and 6.9 to $23.6 \%$, respectively (Table 1). Amongst the various districts surveyed, the highest mean disease incidence of $51.8 \%$ was observed in Baramulla followed by Srinagar $(45.7 \%)$ with least mean disease incidence and intensity of 23.6 and $10.2 \%$ in district Budgam. The high disease severity observed at various locations could be attributed to the practice of maintaining high plant density, non-disposal of plant debris and use of disease susceptible varieties. High plant density creates high relative humidity in microclimate of plants which favours disease development. The moist weather and faulty management were considered as predisposing factors for mildew disease development in cucumber (Hansen, 2009). Similarly variations in anthracnose severity due to variation in environmental conditions have been reported by Thompson and Jenkins (1985) and Zitter et al. (1998). In general it was noticed that the locations wherein practices of maintaining less plant spacing, non-disposal of plant debris and less adoption of package of practices was followed those locations has higher disease severity. Similar findings have been reported by Hajlaoui and Belanger (1991), Wang et al. (2009) and Zhang (2011).

\section{References}

Balai, L.P., Ahir, R.R. 2013. Role of temperature and relative humidity on mycelial growth of Alternaria alternata infecting brinjal. Trends in Biosci., 6: 307-308.

Bains, S.S. and Sharma, N.K. 1986. 
Differential response of certain cucurbits to isolates of Pseudoperonospora cubensis and characteristics of identified races. Phytophylactica, 18: 31-33.

Colucci, S.J., T.C. Wehner, and G.J. Holmes. 2006. The downy mildew epidemic of 2004 and 2005 in the eastern United States. Proc. Cucurbitaceae, 2006: 403-411.

Del Pino, D., Olalla, L., Pérez-García, A., Rivera, M.E., García, S., Moreno, R., de Vicente, A. and Torés, J.A. 2002. Occurrence of races and pathotypes of cucurbit powdery mildew in southeastern Spain. Phytoparasitica, 30: $1-8$.

Doijode, S.D. 2001. Seed Storage of Horticultural Crops. Haworth Press. USA. ISBN 1-56022-901-2 pp. 281

FAOSTAT. 2013. Area and Production of Cucumber and Gherkhins. http://faostat3.fao.org/download/Q/QC $/ \mathrm{E}$

Garibaldi, A., Gilardi, G. and Gullino, M.L. 2007. First report of Alternaria leaf spot on Camellia in Italy. Plant Dis., 91: 324

Goldberg, N.P. 2004. Anthracnose of Cucurbits. Cooperative Extension. College of Agriculture and Home Economics, USA.www.cahe.nmsu.edu .p 2

Gupta, S., Upadhyay, R.N., Kumar, S. and Razdan, V.K. 2014. Integrated management of downy mildew of cucumber. Indian Phytopathol., 67(3): 203-212.

Hajlaoui, M.R. and Bélanger, R.R. 1991. Comparative effects of temperature and humidity on the activity of three potential antagonists of rose powdery mildew. Netherland J. Plant Pathol., 97: 203-208.

Hansen, M.A. 2009. Downy Mildew of
Cucurbits. Extension Plant Pathologist, Department of Plant Pathology, Virginia Polytechnic Institute and State University, USA. www.ext.vt.edu

Hubballi, M., Nakkeeran, S., Raguchander, T., Ananad, T. and Samiyappam, R. 2010. Effect of environmental conditions on growth of Alternaria alternata causing leaf blight of onion. World J. Agri. Sci., 6: 171-177.

Kalloo, G. 1997. Proceedings of the $16^{\text {th }}$ Group Meeting on Vegetable Research. ICAR. TNAU, Coimbatore, India pp. 111-112.

Kumar, N.R., Rai, A.B. and Rai, M. 2008. Export of cucumber and gherkin from India: Performance, destinations, competitiveness and determinants. Agri. Economics Res. Rev., 21: 130138.

Lebeda, A., Sedláková, B., Krístková, E. and Vysoudil, M. 2009. Long-lasting changes in the species spectrum of cucurbit powdery mildew in the Czech Republic- influence of air temperature changes or random effect. Plant Protection Sci., 45: 41-47.

Renner, S.S., Schaefer, H. and Kocyan, A. 2007. Phylogenetics

of Cucumis (Cucurbitaceae):

Cucumber ( $C$. sativus) belongs in an Asian/Australian clade far from melon (C. melo). BMC Evol. Biol., 7: 58.

Reuveni, M. and Reuveni, R. 2000. Prior inoculation with non-pathogenic fungi induces systemic resistance to powdery mildew on cucumber plants. European J. Plant Pathol., 106: 633638.

Rotem, J., Cohen, Y. and Bashi, E. 1978. Host and environmental influences on sporulation in vivo. Annual Review of Phytopathol., 16: 83-101.

Saha, L.R. 2002. Hand Book of Plant Pathology. $1^{\text {st }} \quad$ Edition, Kalyani 
Publishers, New Delhi, India. p. 928.

Shetty, N. and Wehner, T.C. 2002. Screening the cucumber germplasm collection for fruit yield and quality. Crop Sci., 42: 2174-2183.

Singh, P.P., Thind, T.S. and Lal, T. 1996. Reaction of some muskmelon genotype against Pseudoperonospora cubensis under field and artificial epiphytic conditions. Indian Phytopathol., 49: 188-190.

Thakur, R.P. and Mathur, K. 2002. Downy mildews of India. Crop Protection, 21: 333-345.

Thomas, C.E. 1977. Influence of dew on downy mildew of cantaloupe in South Texas. Phytopathol., 67: 1368-1369.

Thomas, C.E. 1996. Downy mildew. In: Compendium of Cucurbit Diseases (Ed. T.A. Zitter). Cornell University Press, Ithaca, New York, USA. pp 2527.

Thompson, D.C. and Jenkins, S.F. 1985. Influence of cultivar resistance, initial disease, environment, and fungicide concentration and timing on anthracnose development and yield loss in pickling cucumbers.
Phytopathol., 75: 1422-1427.

Wang, C.M., Zhou, W., Li, C.X., Chen, H., Shi, Z.Q and Fan, Y.J. 2009. Efficacy of osthol, a potent coumarin compound, in controlling powdery mildew caused by Sphaerotheca fuliginea. J. Asian Natural Products Res., 11(9): 783-791.

Wehner, T.C. and Maynard, D.N. 2003. Cucurbitaceae (Vine Crops). In: The Encyclopedia of Life. John Wiley \& Sons, Nature Publishing, London, UK. 1: 228-236.

Wehner, T.C. and Robinson, R.W. 1991. A brief history of the development of cucumber cultivars in the U.S. Cucurbit Genetics Cooperate Report, 14: 1 .

Zhang, S. 2011. Evaluation of microbial products for management of powdery mildew on summer squash and cantaloupe in Florida. Plant Dis., 95(4): 461-468.

Zitter, T.A., Hopkins, D.L. and Thomas, C.E. 1998. Compendium of Cucurbit Dis., APS Press, St. Paul, Minnesota, USA. p. 87.

\section{How to cite this article:}

Shanaz Yousuf and G.H. Dar. 2016. Prevalence and Status of Major Fungal Foliar Diseases of Cucumber in Western Himalayan State of Jammu \& Kashmir. Int.J.Curr.Microbiol.App.Sci. 5(7): 550-557. doi: http://dx.doi.org/10.20546/ijcmas.2016.507.060 